\title{
The influence of dietary soyabean and linseed on the chemical composition and fatty acid profile of the Longissimus muscle of feedlot-finished bulls
}

\author{
I.N. Prado ${ }^{1,3}$, R.H. Ito ${ }^{1}$, J.M. Prado ${ }^{1}$, I.M. Prado ${ }^{1}$, P.P. Rotta ${ }^{1}$, \\ M. Matsushita ${ }^{2}$, J.V. Visentainer ${ }^{2}$ and R.R. Silva ${ }^{1}$
}

\author{
State University of Maringá, \\ ${ }^{1}$ Animal Science Department, \\ ${ }^{2}$ Chemistry Department \\ Av. Colombo 5790, CEP 87020-900, Maringá, PR, Brazil
}

(Received 28 November 2007; revised version 27 May 2008; accepted 24 June 2008)

\begin{abstract}
This work was carried out to evaluate the effect of soya and linseed on the chemical composition and fatty acid profile of the Longissimus muscle of crossbred bulls finished in feedlot. Twenty-one crossbred bulls ( $1 / 2$ Nelore vs $1 / 2$ Simmenthal), at an average age of 18 months were used in a completely randomized design, with three treatments and seven repetitions. The dietary treatments were: control (CON), linseed and soyabean (SOYA), and soyabean and linseed added after the $60^{\text {th }}$ day of the experiment (LIN). No difference $(\mathrm{P}>0.05)$ was observed among the treatments on the chemical composition of the Longissimus muscle. The values of conjugated linoleic acid $(18: 2-c-9, t-11)$ were higher $(\mathrm{P}<0.05)$ in the $\operatorname{LIN}(0.39 \%)$ and SOYA $(0.46 \%)$ treatment, as compared with the CON treatment $(0.26 \%) . n-3$ PUFA values were higher $(\mathrm{P}<0.05)$ in the LIN treatment $(1.58 \%)$ as compared with the CON treatment $(0.83 \%)$.
\end{abstract}

KEY WORDS: linseed, soyabean oil, PUFA, meat, bulls

\section{INTRODUCTION}

Brazil has the largest commercial cattle population in the world, with approximately 159 million animals and a production of approximately 8.2 million tons of carcass each year (Anualpec, 2007). From this total, about 30\% (2.4 million tons) is exported to several countries around the world.

The concept that certain foods or food components have benefits that extend beyond their traditional nutritional values has raised awareness and acceptance among customers. Food products have been shown to contain micro-components

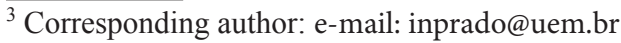


that have positive effects on human health and prevention of diseases greater than those credited to traditional nutritional values alone (Bauman and Griinari, 2001).

According to Beaulieu et al. (2002), the consumption of red meat in the last two decades has been hampered by public interest regarding total fat and saturated fatty acid contents in beef. As such, there is an incentive to produce beef with high levels of fatty acids as healthy as conjugated linoleic acid (CLA). CLA, discovered in 1979, refers to a mixture of linoleic acid isomers (C 18:2) that occur in low levels ( $<1 \%$ of total fatty acids) (Schimid et al., 2006). Several studies since then have confirmed its anti-carcinogenic properties (Pariza et al., 2001). In addition, CLA has gained attention for its health-related biological properties, including reduction in body fat, anti-diabetic effect and reduction in the development of arthrosclerosis, among others (Chouinard et al., 1999).

In recent years, researchers have explored the possibility of increasing the beneficial effects of animal products (milk, meat and eggs) through manipulation of animal diets. Foods such as milk and meat from ruminants (Pariza and Ha, 1990) are primary sources of conjugated linoleic acid (CLA) for humans. An alternative could be the use of finishing diets for animals containing whole seeds or oils with high levels of linoleic and linolenic fatty acids in order to increase CLA concentrations.

Among available oil sources, soyabean oil could be used because of its availability and cost. Furthermore, soyabean oil undergoes biohydrogenation in the rumen, leading to the formation of vaccenic acid, which is a precursor of CLA. Therefore, an increase in the levels of vaccenic acid in the rumen could lead to greater CLA synthesis and deposition in the muscle tissue of animals. Linseed performs differently. It is rich in $n-3$ and $n-6$ fatty acids. Its hull is hard and firm, which could prevent its breakdown in the rumen and enable it to reach the small intestine as fat escape. After its hydrolysis by pancreatic enzymes, it could be absorbed with a composition similar to primary fats.

Some alternative energy sources, such as whole cottonseed, rapeseeds, linseeds, and soyabean, soyabean oil, maize oil and sunflower oil, as well as added fat could be part of the diet of ruminants, with the objective of raising the levels of monoand polyunsaturated fatty acids.

The objective of this study was to evaluate the use of linseed and soyabean oil on the chemical composition (moisture, ash, crude protein, total lipids and total cholesterol) and fatty acid profile of the Longissimus of feedlot-finished young bulls.

\section{MATERIAL AND METHODS}

\section{Animals and management}

The Committee of Animal Production at Maringá State University approved this experiment, which was carried out at the Iguatemi Research Farm in the town of Iguatemi, northwestern Paraná (Brazil). Twenty-one (1/2 Nellore vs 1/2 Simmen- 
thal) bulls at an initial average age of 18 months were used. The meat analyses were carried out at the Chemical Laboratory of the State University of Maringá.

The bulls were kept in individual pens $\left(10 \mathrm{~m}^{2}\right.$ per animal) and fed twice daily. They were given access to a diet formulated to meet requirements for fattening beef cattle (NRC, 1996). The formulation and quantity of the diet fed to the animals were intended to reach a weight gain of $1.20 \mathrm{~kg} /$ day, according to NRC (1996). The treatments used were: control - CON - 32\% concentrate containing maize; soyabean oil - SOYA and linseed - LIN - 27\% concentrate containing linseed, 60 days after the beginning of the study, in order to verify whether incorporation of C 18:3n-3 in the meat would occur with a shorter supply time (Tables 1 and 2). Maize silage was used as roughage for all three treatments. The complete rations (roughage + concentrate) were fed in the morning ( 8 a.m.) and in the afternoon ( 4 p.m.)

Table 1 . Fatty acids profile of diets, $\%$

\begin{tabular}{lrrr}
\hline \multirow{2}{*}{ Fatty acids } & \multicolumn{3}{c}{ Treatments } \\
\cline { 2 - 4 } & CON $^{1}$ & LIN $^{2}$ & SOYA $^{3}$ \\
\hline C 16:0 Palmitic acid & 15.18 & 13.19 & 13.02 \\
C 18:0 Stearic acid & 2.44 & 2.85 & 2.91 \\
C 18:1 n-9 Oleic acid & 31.32 & 29.81 & 28.99 \\
C 18:2 n-6 Linoleic acid & 47.26 & 42.32 & 42.29 \\
C 18:3 n-3 a Linolenic acid & 3.79 & 11.81 & 12.80 \\
\hline
\end{tabular}

${ }^{1}$ control ration; ${ }^{2}$ ration with whole linseed; ${ }^{3}$ ration with soya oil and whole linseed 60 days after experiment begin

Table 2. Chemical composition of the ingredients and experimental diets, $\% \mathrm{DM}$

\begin{tabular}{|c|c|c|c|c|c|c|c|c|}
\hline \multirow{2}{*}{ Ingredients } & \multirow{2}{*}{$\mathrm{DM}$} & \multicolumn{7}{|c|}{$\% \mathrm{DM}$} \\
\hline & & ash & $\mathrm{OM}$ & $\mathrm{CP}$ & NDF & $\mathrm{ADF}$ & GE & $\mathrm{EE}$ \\
\hline Maize silage & 33.50 & 4.60 & 95.40 & 7.50 & 45.74 & 29.42 & 4.44 & 3.05 \\
\hline Ground maize grain & 89.11 & 1.04 & 98.96 & 8.00 & 12.64 & 3.11 & 4.32 & 3.70 \\
\hline Linseed & 93.52 & 3.45 & 96.55 & 23.09 & 48.39 & 34.75 & 6.50 & 40.41 \\
\hline Soya oil & 99.80 & & & & & & 9.73 & 100.00 \\
\hline Soyabean meal & 88.62 & 4.91 & 95.09 & 50.78 & 14.96 & 11.10 & 4.71 & 1.80 \\
\hline Limestone & 99.90 & 99.54 & 0.46 & & & & & \\
\hline Mineral salt & 98.71 & 89.29 & 10.71 & & & & & \\
\hline Urea & 98.80 & & & 273.63 & & & & \\
\hline \multicolumn{9}{|l|}{$\%$ diets } \\
\hline $\mathrm{CON}^{1}$ & 56.81 & 4.67 & 95.35 & 9.95 & 32.61 & 19.47 & 4.36 & 3.08 \\
\hline $\mathrm{LIN}^{2}$ & 55.07 & 4.65 & 87.71 & 10.43 & 33.23 & 20.60 & 4.57 & 7.20 \\
\hline SOYA $^{3}$ & 59.35 & 4.63 & 95.37 & 10.94 & 29.63 & 18.19 & 4.61 & 8.53 \\
\hline
\end{tabular}




\section{Chemical composition}

The bulls were slaughtered at a commercial slaughterhouse $40 \mathrm{~km}$ away from the farm (Colorado, Paraná), according to industrial practice in Brazil. After slaughter, the carcasses were identified and chilling for $24 \mathrm{~h}$ at $4^{\circ} \mathrm{C}$. Laboratory analyses of beef were carried out two months after sampling. The samples were thawed at room temperature $\left(20^{\circ} \mathrm{C}\right)$, ground, homogenized, and analysed in triplicate. Beef moisture and ash contents were determined according to AOAC (1998). Crude protein content by the Kjeldahl method (AOAC, 1998). Total lipids were extracted by the Bligh and Dyer method (1959) with a chloroform/methanol mixture. Fatty acid methyl esters (FAME) were prepared by triacylglycerol methylation, according to the ISO method (1978).

\section{Cholesterol quantification}

Cholesterol analysis was carried out by the method modified by Rowe et al. (1999). A $60 \%(\mathrm{w} / \mathrm{v})$ solution of potassium hydroxide was added to the samples in quantities equivalent to $2 \mathrm{ml} \mathrm{h}^{-1}$ of sample under 1-h reflux. The residue was dissolved again in $2 \mathrm{ml}$ hexane containing $0.2 \mathrm{mg} \mathrm{ml}^{-1} 5-\alpha$ cholestane internal standard (IS) (Sigma, USA).

Cholesterol content was analysed using a 14-A gas chromatograph (Shimadzu, Japan), equipped with a flame ionization detector and a fused silica capillary column ( $25 \mathrm{~m}$ long, 0.25 - $\mathrm{mm}$ internal diameter, and $0.20 \mu \mathrm{m}$ Ohio Valley-30). Injector, column, and detector temperatures were 260,280 , and $280^{\circ} \mathrm{C}$, respectively.

\section{Analysis of fatty acid methyl esters}

The fatty acid methyl esters (FAMEs) were analysed using a gas chromatograph (Varian, USA) equipped with a flame ionization detector and a fused silica capillary column CP-7420 (100 m, $0.25 \mathrm{~mm}$ and $0.39 \mu \mathrm{m}$ o.d., Varian, USA) Select Fame. Column temperature was programmed at $165^{\circ} \mathrm{C}$ for $18 \mathrm{~min}, 180^{\circ} \mathrm{C}$ $\left(30^{\circ} \mathrm{C} \mathrm{min}-1\right)$ for $22 \mathrm{~min}$, and $240^{\circ} \mathrm{C}\left(15^{\circ} \mathrm{C} \mathrm{min}{ }^{-1}\right)$ for $30 \mathrm{~min}, 45$-psi pressure. The injector and detector were kept at $220^{\circ} \mathrm{C}$ and $245^{\circ} \mathrm{C}$, respectively. The gas fluxes

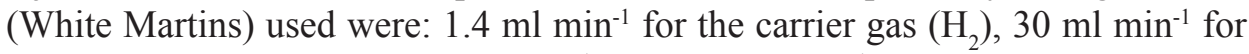
the make-up gas $\left(\mathrm{N}_{2}\right)$ and $30 \mathrm{ml} \mathrm{min}-1$ and $300 \mathrm{ml} \mathrm{min}^{-1}$ for $\mathrm{H}_{2}$ and the synthetic flame gas, respectively. Sample injection split mode was 1/80.

\section{Experiment design and statistical analysis}

The experiment design was completely randomized, with three treatments and seven repetitions. The data were submitted to analysis of variance, and the 
averages (when different) were compared using the Tukey test at 5\% significance levels, using SAS statistical software (2000), according to the following mathematical model:

$$
\mathrm{Y}_{\mathrm{ij}}=\mu+\mathrm{t}_{\mathrm{i}}+\mathrm{e}_{\mathrm{ij}}
$$

where: $Y_{i j}$ - observation of animal $j$, subjected to treatment $i ; \mu$ - overall constant; $t_{i}$ - treatment effect $i ; i-1 ; \ldots ; 3 ; e_{i j}$ - random error associated with each $\mathrm{Y}_{\mathrm{ij}}$ observation.

\section{RESULTS}

There were no differences $(\mathrm{P}>0.05)$ among treatments in percentages of moisture, ash, crude protein, total lipids and total cholesterol in the Longissimus muscle of feedlot-finished animals (Table 3).

Table 3. Percentage of moisture, ash, crude protein, fat and cholesterol concentration of the Longissimus muscle of feedlot steer

\begin{tabular}{|c|c|c|c|c|c|}
\hline \multirow{2}{*}{ Parameters } & \multicolumn{3}{|c|}{ Treatments } & \multirow{2}{*}{$\mathrm{SE}^{4}$} & \multirow{2}{*}{$\mathrm{P}>\mathrm{F}$} \\
\hline & $\mathrm{CON}^{1}$ & $\mathrm{LIN}^{2}$ & SOYA $^{3}$ & & \\
\hline Moisture, \% & 74.07 & 74.87 & 74.99 & 0.34 & NS \\
\hline Ash, \% & 1.03 & 1.06 & 1.00 & 0.01 & NS \\
\hline Crude protein, $\%$ & 20.41 & 19.87 & 20.33 & 0.48 & NS \\
\hline Fatty acids, $\%$ & 2.31 & 1.86 & 2.73 & 0.23 & NS \\
\hline Cholesterol $^{5}$ & 54.24 & 55.35 & 53.60 & 1.07 & NS \\
\hline
\end{tabular}

${ }^{1}$ control ration; ${ }^{2}$ ration with whole linseed; ${ }^{3}$ ration with soya oil and whole linseed 60 days after experiment begin; ${ }^{4}$ standard errors; ${ }^{5} \mathrm{mg} / 100 \mathrm{~g}$ muscle; NS - non-significant

The fatty acid profile of the Longissimus muscle is given in Table 4. There were no observed differences $(\mathrm{P}>0.05)$ for: capric acid $(\mathrm{C} 10: 0)$; lauric acid (C 12:0); myristic acid (C 14:0); C 14:1cis-9 acid; pentadecilic acid (C 15:0); C 15:1n-5 acid; 7-hexadecenoic acid (C16:1n-9); 11-hexadecenoic acid (C 16:1n-5); stearic acid (C 18:0); oleic acid (C 18:1n-9); linoleic acid (C 18:2n-6); $\gamma$-linoleic acid (C18:3n-6); $\alpha$-linoleic acid (C18:3n-3); arachdonic acid (C 20:4n-6); eicosapentaenoic acid (C20:5n-3), and docosahexaenoic acid (C 22:6n-3) among treatments.

Palmitoleic acid $(\mathrm{C} 16: 1 n-7)$ showed a lower level $(\mathrm{P}<0.05)$ for the LIN $(2.35 \%)$ and SOYA $(2.13 \%)$ treatments, as compared with CON $(2.93 \%)$. However, no difference was observed $(\mathrm{P}>0.05)$ between LIN and SOYA treatments. Margaric acid (C17:0) was present at a lower level $(\mathrm{P}<0.05)$ in the LIN $(0.63 \%)$ and SOYA $(0.66 \%)$ treatments, as compared with CON $(0.81 \%)$. 
Table 4. Diet effects on the fatty acid profile Longissimus muscle of feedlot steers, $\%$

\begin{tabular}{|c|c|c|c|c|c|}
\hline \multirow{2}{*}{ Fatty acids } & \multicolumn{3}{|c|}{ Treatments } & \multirow{2}{*}{$\mathrm{SE}^{4}$} & \multirow{2}{*}{$\mathrm{P}>\mathrm{F}$} \\
\hline & $\mathrm{CON}^{1}$ & $\mathrm{LIN}^{2}$ & SOYA $^{3}$ & & \\
\hline C 10:0 capric acid & 0.09 & 0.10 & 0.10 & 0.01 & NS \\
\hline C 12:0 lauric acid & 0.08 & 0.08 & 0.07 & 0.01 & NS \\
\hline C 14:0 myristic acid & 2.79 & 2.43 & 2.31 & 0.23 & NS \\
\hline C $14: 1$ cis-9 acid & 0.53 & 0.41 & 0.36 & 0.07 & NS \\
\hline C 15:0 pentadecilic acid & 0.30 & 0.28 & 0.27 & 0.03 & NS \\
\hline C $15: 1 n-5$ acid & 0.18 & 0.18 & 0.18 & 0.02 & NS \\
\hline C 16:0 palmitic acid & $29.2^{\mathrm{a}}$ & $25.2^{\mathrm{b}}$ & $25.56^{\mathrm{b}}$ & 0.86 & 0.05 \\
\hline C 16:1 n-9 7-hexadecenoic acid & 0.35 & 0.37 & 0.35 & 0.02 & NS \\
\hline C $16: 1 n-7$ palmitoleic acid & $2.92^{\mathrm{a}}$ & $2.35^{\mathrm{ab}}$ & $2.12^{\mathrm{b}}$ & 0.23 & 0.05 \\
\hline C 16:1 n-5 11-hexadecenoic acid & 0.50 & 0.43 & 0.45 & 0.02 & NS \\
\hline C 17:0 margaric acid & $0.81^{\mathrm{a}}$ & $0.63^{\mathrm{b}}$ & $0.66^{\mathrm{ab}}$ & 0.05 & 0.05 \\
\hline C 17:1 n-9 8-heptadecenoic acid & $0.63^{\mathrm{a}}$ & $0.51^{\mathrm{b}}$ & $0.49^{\mathrm{b}}$ & 0.03 & 0.05 \\
\hline C 18:0 stearic acid & 16.0 & 17.6 & 18.5 & 1.30 & NS \\
\hline C 18:1 trans-11 vaccenic acid & $0.88^{\mathrm{b}}$ & $1.03^{\mathrm{b}}$ & $1.76^{\mathrm{a}}$ & 0.14 & 0.05 \\
\hline C 18:1 n-9 oleic acid & 38.7 & 38.5 & 39.2 & 1.06 & NS \\
\hline C 18:2 n-6 linoleic acid & 3.87 & 5.62 & 4.87 & 0.68 & NS \\
\hline C $18: 3 n-6$ linolenic acid & 0.26 & 0.33 & 0.30 & 0.09 & NS \\
\hline C 18:3n-3 a-linoleic acid & 0.24 & 0.64 & 0.51 & 0.10 & NS \\
\hline C 18:2c-9 t-11 CLA & $0.26^{\mathrm{b}}$ & $0.39^{\mathrm{a}}$ & $0.46^{\mathrm{a}}$ & 0.03 & 0.05 \\
\hline C 20:4 n-6 arachdonic acid & 0.76 & 1.17 & 0.89 & 0.12 & NS \\
\hline C 20:5 n-3 eicosapentaenoic acid (EPA) & 0.19 & 0.33 & 0.23 & 0.04 & NS \\
\hline C 22:6n-3 docosahexaenoic acid (DHA) & 0.40 & 0.61 & 0.45 & 0.06 & NS \\
\hline
\end{tabular}

${ }^{1}$ control ration; ${ }^{2}$ ration with whole linseed; ${ }^{3}$ ration with soya oil and added whole linseed 60 days after experiment begin; ${ }^{4}$ standard errors; NS - non-significant

No difference was observed $(\mathrm{P}>0.05)$ between the LIN and SOYA treatments. 8Heptadecenoic acid $(\mathrm{C} 17: 1 \mathrm{n}-9)$ was present at a lower level $(\mathrm{P}<0.05)$ in the LIN $(0.51 \%)$ and SOYA $(0.49 \%)$ treatments as compared with CON $(0.63 \%)$. However, no differences were observed $(\mathrm{P}>0.05)$ between the LIN and SOYA treatments. The value of vaccenic acid (C 18:1 trans-11) was higher $(\mathrm{P}<0.05)$ in the SOYA treatment $(1.76 \%)$, as compared with CON $(0.89 \%)$ and LIN $(1.03 \%)$. However, there were no differences $(\mathrm{P}>0.05)$ between the $\mathrm{CON}$ and LIN treatments.

The values of conjugated linoleic acid $(\mathrm{C} 18: 2 c-9, t-11)$ were greater $(\mathrm{P}<0.05)$ in the LIN $(0.39 \%)$ and SOYA $(0.46 \%)$ treatments, as compared with CON $(0.26 \%)$. However, there was no difference $(\mathrm{P}>0.05)$ between the LIN and SOYA treatments.

No differences were found $(\mathrm{P}>0.05)$ among treatments in the percentages of SFA, MUFA, PUFA, $n-6$, PUFA:SFA and $n-6: n-3$ (Table 5). The only difference found among treatments $(\mathrm{P}<0.05)$ was in $n-3$ levels. 
Table 5. Proportion (\%) of saturated fatty acids (SFA). monounsaturated fatty acids (MUFA), polyunsaturated fatty acids (PUFA), fatty acids $n-6$, fatty acids $n-3$, PUFA:SFA and $n-6: n-3$ ratio of the Longissimus muscle of feedlot steers

\begin{tabular}{lccccc}
\hline \multirow{2}{*}{ Fatty acids } & \multicolumn{3}{c}{ Treatments } & \multirow{2}{*}{ SE $^{4}$} & \multirow{2}{*}{$\mathrm{P}>\mathrm{F}$} \\
\cline { 2 - 3 } SFA & $\mathrm{CON}^{1}$ & LIN $^{2}$ & SOYA $^{3}$ & & \\
MUFA & 49.20 & 46.90 & 47.30 & 0.90 & $\mathrm{NS}$ \\
PUFA & 44.80 & 43.97 & 44.97 & 0.88 & NS \\
$n-6$ & 5.99 & 9.10 & 7.71 & 0.78 & NS \\
$n-3$ & 4.90 & 7.11 & 6.07 & 0.64 & NS \\
PUFA:SFA ratio & $0.83^{\mathrm{b}}$ & $1.58^{\mathrm{a}}$ & $1.19^{\mathrm{ab}}$ & 0.17 & 0.05 \\
$n-6: n-3$ ratio & 0.12 & 0.20 & 0.16 & 0.02 & NS \\
\hline
\end{tabular}

${ }^{1}$ control ration; ${ }^{2}$ ration with whole linseed; ${ }^{3}$ ration with soya oil and whole linseed 60 days after experiment begin; ${ }^{4}$ standard errors; NS - non-significant

\section{DISCUSSION}

The observed average value for moisture was $74.6 \%$. Similar results were reported by Silva et al. (2002) in crossbred heifers (Limousin vs Nellore and Simmenthal vs Nellore), approximately 18 months old, with an average moisture level of $74.6 \%$. Higher levels were obtained by Abularach et al. (1998) in Nellore young bulls aged 23-29 months, feedlot-finished, with an average moisture level of $75.6 \%$. Thus, the level of moisture in the Longissimus muscle shows little variation as a function of diet (Padre et al., 2006).

The average ash percentage (1.03\%) was similar to results observed by Padre et al. (2007) - $1.00 \%$.

The average level for crude protein (20.20\%) is satisfactory. Silva et al. (2002) and Padre et al. (2007) found higher levels of protein, with an average value of 23.0 and $23.2 \%$, respectively.

The average level for total lipids was $2.3 \%$. The level of total lipids for feedlotfinished cattle varies as a result of different breeds. Padre et al. (2007) observed lower values of total lipids than in this study, with an average of $1.35 \%$. Lower results than in our experiment were observed by Abularach et al. (1998), where the average value was $1.71 \%$. These authors state that low levels of intramuscular fat can compromise the juiciness and tenderness of striploin, which is a meat for fast grilling in dry heat. There is evidence that the lowest lipid content required for a tender and juicy steak is $3.0 \%$.

The average level for total cholesterol was $54.40 \mathrm{mg} / 100 \mathrm{~g}$ of meat. Higher values were obtained by Andrae et al. (2001), who evaluated diets containing maize with high oil levels in confined young bulls, with an average obtained value 
of $56.20 \mathrm{mg} / 100 \mathrm{~g}$. Padre et al. (2007) found a total cholesterol level of 43.22 $\mathrm{mg} / 100 \mathrm{~g}$ in the Longissimus muscle. However, similar results to this experiment were obtained by Padre et al. (2006), who analysed a sample of striploin and found a value of $52.00 \mathrm{mg} / 100 \mathrm{~g}$ of muscle. According to Hood (1987), when lipid amounts in the muscle are low, the cholesterol concentration is high.

Current recommendations are to keep cholesterol levels under control, and not necessarily eliminate them from the diet. However, saturated fat intake must be kept under strict control, as it can raise cholesterol levels in the bloodstream. Cholesterol intake must be limited to $300 \mathrm{mg} /$ day (HMSO, 1994).

Palmitic acid (C 16:0) featured lower levels $(\mathrm{P}<0.05)$ for LIN $(25.97 \%)$ and SOYA $(25.55 \%)$ treatments, as compared with CON (29.27\%). However, there was no observed difference $(\mathrm{P}>0.05)$ between the LIN and SOYA treatments. Similar results to this experiment were observed by Beaulieu et al. (2002). Higher levels were obtained by Mir et al. (2002), who used 6\% sunflower oil in young beef bulls from the Wagyu, Wagyu vs Limousin and Limousin breeds, for which they found average values of $4.63 \%$ for myristic acids (C 14:0) and $30.36 \%$ for palmitic acid (C 16:0).

One of the fat components that offers the greatest health risks are saturated fatty acids (Pariza et al., 2001). However, not all saturated fatty acids act equally. Lauric (C 12:0), myristic (C 14:0) and palmitic (C 16:0) fatty acids raise levels of LDL-cholesterol in the bloodstream. A similar effect is caused by the intake of hydrogenated fats (made up of unsaturated fatty acids, in trans form, contained in margarine and lards of animal and vegetable origin). Furthermore, hydrogenated fat reduces levels of HDL-cholesterol (protective cholesterol), with possible health risks as a result (Pensel, 1998).

Mensink and Zock (1998) observed that 18:1 trans increases, in particular, the concentration of low density lipoprotein (LDL). Therefore, diets should not only be low in saturated fatty acids, but low in trans fatty acids as well. The case of vaccenic acid (C 18:1 trans 11) is different, because it is produced during biohydrogenation of linoleic acid (C 18:2 n-6) in the rumen (Tamminga and Doreau, 1991), which serves as a precursor for the endogenous synthesis of conjugated linoleic acid (CLA, C 18:2 c-9 $t$-11) by $\Delta^{9}$ desaturase (Griinari et al., 2000).

Linoleic acid (C 18:2 n-6), $\alpha$-linolenic acid (C 18:3n-3) and arachdonic acid (C 20:4n-6) are considered essential fatty acids for the complete nutrition of several animal species, including humans, and thus must be present in diet because they cannot be synthesized in the body (Khanal, 2004). However, arachdonic acid (C 20:4 n-6) can be synthesized from linoleic acid (C 18:2n-6).

The average observed value for SFA in this experiment was $47.80 \%$. Lower results were reported by Silva et al. (2002) and Prado et al. (2003), who obtained average results of 44.26 and $44.58 \%$, respectively. 
The average obtained value for MUFA in this experiment was $44.68 \%$. Higher levels were obtained by Prado et al. (2003), with an average value of $46.00 \%$, but lower value were reported by Silva et al. (2002), who obtained an average result of $42.88 \%$. The average observed value for PUFA in this experiment was $7.60 \%$. Prado et al. (2003) observed higher levels, with average results of 11.10 and $9.14 \%$, respectively.

The average observed value for $n-6$ in this experiment was $6.02 \%$. Lower results were found by Silva et al. (2002), with an average value of $5.69 \%$. Prado et al. (2003) observed higher levels, with an average value of $9.14 \%$.

No difference was found $(\mathrm{P}>0.05)$ in the PUFA:SFA ratio, with an average value of 0.16 , this value is lower than 0.40, which is recommended by the English Health Department (HMSO, 1994). The PUFA/SFA ratio is important for health because it reduces the risk of coronary disease, although the optimal ratio has been a matter of debate $(\mathrm{Hu}, 2001)$.

The levels of omega- 6 fatty acids were not influenced by the two different sources of fat used in the diet (soyabean oil or linseed). However, linseed raised the levels of omega-3 in the Longissimus muscle. This increase in omega-3 levels could be related to the concentration of that acid in linseed. It could then undergo biohydrogenation in the rumen, which would lead to the formation of large amounts of saturated acid. However, this biohydrogenation could be prevented by the type of linseed tegumentation, which could in turn protect the seed inside the rumen and allow it to reach the small intestine still in its primary composition, leading to its absorption by the muscle as unsaturated fatty acids.

There were no differences $(\mathrm{P}>0.05)$ in the $n-6: n-3$ ratio, with an average value of 5.55. Lower ratios were observed by Silva et al. (2002) and Prado et al. (2003) with average values of 1.27 and 2.78 , respectively. In general, the $n-6: n-3$ ratio is influenced by the fatty acid composition of animal diets. The inclusion of $n-3$ sources in the animal's diet increases total $n-3$ content, with a decrease in intramuscular $n-6$ fatty acid deposition. Ruminants finished with grazing can reduce the $n-6: n-3$ ratio to levels lower than 2 , whereas in ruminants fed concentrate this ratio remains around 6 to 10 (Raes et al., 2004; Padre et al., 2007). Nevertheless, the $n-6: n-3$ ratio found in this study is close to that considered ideal for human health.

\section{CONCLUSIONS}

Partial replacement of maize by soyabean oil (SOYA) or linseed (LIN) did not affect the chemical composition (moisture, ash, crude protein, total lipids and total cholesterol) of the Longissimus muscle of feedlot-finished young bulls. Therefore, 
the change in the feeding regimen of ruminants does not alter carcass chemical composition. There was a difference in the fatty-acid profile with the LIN and SOYA treatments, as compared with the control treatment. The change in the fatty-acid profile of the Longissimus muscle of young, feedlot-finished bulls brought about by using soyabean oil or linseed is beneficial to human health. There was a reduction in some saturated fatty acids (which reduces low-density cholesterol), and an increase in conjugated linoleic acid (anticarcinogen) as well as in $n-3$, which are important in fighting atherosclerosis.

\section{REFERENCES}

Abularach M.L.S., Rocha C.E., Felício P.E., 1998. Quality characteristics of muscle Longissimus of young Nellore bulls. Ciên. Tecnol. Alim. 18, 205-210

Andrae J.G., Duckett S.K., Hunt C.W., Pritchard G.T., Owens F.N., 2001. Effects of feeding high-oil corn to beef steers on carcass characteristics and meat quality. J. Anim. Sci. 79, 582-588

Anualpec, 2007. Annual of Brazilian Livestock. São Paulo: FNP Institut, pp. 368

AOAC, 1980. Association of Official Analitical Chemists, Official Methods of Analysis. 14th Edition. Arlington, VA

Bauman D.E., Griinari J.M., 2001. Regulation and nutritional manipulation of milk fat: low-fat milk syndrome. Livest. Prod. Sci. 70, 15-29

Beaulieu A.D., Drackley J.K., Merchen N.R., 2002. Concentrations of conjugated linoleic acid (cis-9, trans-11-octadecadienoic acid) are not increased in tissue lipids of cattle fed a high-concentrate diet supplemented with soybean oil. J. Anim. Sci. 80, 847-861

Bligh E.G., Dyer W.J., 1959. A rapid method of total lipid extraction and purification. Can. J. Biochem. Physiol. 37, 911-917

Chouinard P.Y., Corneau A.S., Bauman D.E., 1999. Milk yield and composition during abomasal infusion of conjugated linoleic acids in dairy cows. J. Dairy Sci. 82, 2737-2745

Griinari J.M., Corl S.H., Lacy S.H., Chouinard P.Y., Nurmela K.V.V., Bauman D.E., 2000. Conjugated linoleic acid is synthesised endogenously in lactating dairy cows by $\Delta^{9}$-desaturase. J. Nutr. 130, 2285-2291

HMSO, 1994. Department of Health. Nutritional Aspects of Cardiovascular Disease: HMSO. Report on Health and Social Subjects. 46, pp. 37-46

Hood R.L., 1987. A note of the cholesterol content of beef rib steaks. CSIRO Food Res. 47, 44-46

Hu F.B., 2001. The balance between $\omega-6$ and $\omega-3$ fatty acids and the risk of coronary heart disease. Nutrition 17, 741-742

ISO, 1978. Animal and Vegetable Fats and Oils - Preparation of Methyl Esters of Fatty Acids. Method ISO 5509

Khanal R.C., 2004. Potential health benefits of conjugated linoleic acid (CLA): a review. AsianAustr. J. Anim. Sci. 17, 1315-1328

Mensink R.P., Zock P.L., 1998. Lipoprotein metabolism and trans fatty acids. In: J.L. Sebedio, W.W. Christie (Editors). Trans Fatty Acids in Human Nutrition. The Oil Press, Dundee (UK), pp. 217-234

Mir P.S., Mir Z., Kuber P.S., Gaskins C.T., Martin E.L., Dodson M.V., Elias Calles L.A., Johnson J.R., Busboom A.J., Pittenger G.J., Reeves J.J., 2002. Growth, carcass characteristics, muscle conjugated linoleic acid (CLA) content, and response to intravenous glucose challenge in high 
percentage Wagyu, Wagyu x Limousin steers fed sunflower oil-containing diets. J. Anim. Sci. 80, 2996-3004

NRC, 1996. Nutrient Requirements of Beef Cattle. $7^{\text {th }}$ revised Edition. National Academy Press. Washington, DC

Padre R.G., Aricetti J.A., Gomes S.T.M., Goes R.H.T.B., Moreira F.B., Prado I.N., Visentainer J.V., Souza N.E., Matsushita M., 2007. Analysis of fatty acids in Longissimus muscle of steers of different genetic breeds finished in pasture systems. Livest. Sci. 110, 57-63

Padre R.G., Aricetti J.A., Moreira F.B., Mizubuti I.Y., Prado I.N., Visentainer J.V., Souza N.E., Matsushita M., 2006. Fatty acids profile, and chemical composition of Longissimus muscle of bovine steers and bulls finished in pasture system. Meat Sci. 74, 242-248

Pariza M.W., Ha Y.L., 1990. Conjugated dienoic derivatives of linoleic acid: a new class of anticarcinogens. Med. Oncol. Tumor Pharmacother. 7, 169-171

Pariza M.W., Park Y., Cook M.E., 2001. The biologically active isomers of conjugated linoleic acid. Prog. Lipid Res. 40, 283-298

Pensel N., 1998. The future for red meat in human diets. Nutr. Abstr. Rev., Ser A 68, 1-4

Prado I.N., Moreira F.B., Matsushita M., Souza N.E., 2003. Longissimus dorsi fatty acids composition of Bos indicus and Bos indicus x Bos taurus crossbred steers finished in pasture. Braz. Arch. Biol. Technol. 46, 601-608

Raes K., Fievez V., Chow T.T., Ansorena D., Demeyer D., De Smet S., 2004. Effect of diet and dietary fatty acids on the transformation and incorporation of $\mathrm{C} 18$ fatty acids in double-muscled Belgian Blue young bulls. J. Sci. Agr. Food Chem. 52, 6035-6041

Rowe A., Macedo F.A.F., Visentainer J.V., Souza N.E., Matsushita M., 1999. Muscle composition and fatty acid profile in lambs fattened in drylot or pasture. Meat Sci. 51, 283-288

SAS, 2000. User's Guide: Statistics, Version 8.1. SAS Institute Inc. Cary, NC

Schimid A., Collomb M., Sieber R., Bee G., 2006. Conjugated linoleic acid in meat and meat products: a review. Meat Sci. 73, 29-41

Silva R.G., Prado I.N., Matsushita M., Souza N.E., 2002. Dietary effects on muscle fatty acid composition of finished heifers. Pesq. Agrop. Bras. 37, 95-101

Tamminga S., Doreau M., 1991. Lipids and rumen digestion. In: J.P. Houany (Editor). Rumen Microbial Metabolism and Ruminant Digestion. INRA, Paris, pp. 151-164 